\title{
WEED TEGHNOLOGY
}

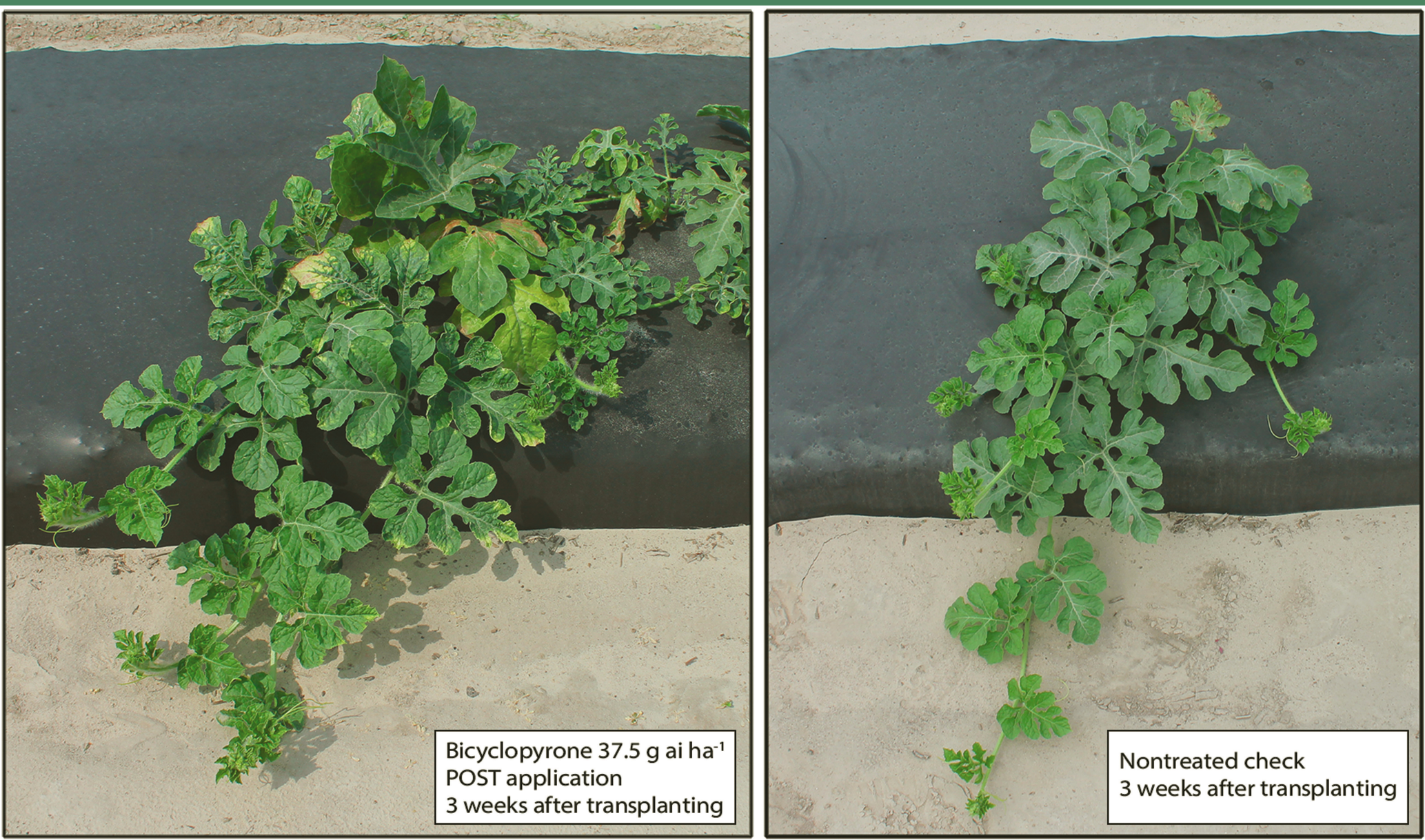




\section{Published six times a year by the Weed Science Society of America}

Jason K. Norsworthy, Editor

The Weed Science Society of America publishes original research and scholarship in the form of peer-reviewed articles in three international journals. Weed Science is focused on understanding "why" phenomena occur in agricultural crops. As such, it focuses on fundamental research directly related to all aspects of weed science in agricultural systems. Weed Technology focuses on understanding "how" weeds are managed. As such, it is focused on more applied aspects concerning the management of weeds in agricultural systems. Invasive Plant Science and Management is a broad-based journal that focuses not only on fundamental and applied research on invasive plant biology, ecology, management, and restoration of invaded non-crop areas, but also on the many other aspects relevant to invasive species, including educational activities, policy issues, and case study reports. Topics for Weed Technology include all aspects of weed management in agricultural, horticultural, ornamental, forestry, aquatic, turf, recreational, rights-of-ways, and other settings; weed resistance to herbicides; herbicide resistant crops; biological weed control agents; new weed management techniques; impacts of weed competition with crops; vegetation management with plant growth regulators; weed surveys; weed-related grower surveys; education; and extension. Symposia papers and reviews are accepted. Consult the editor for additional information.

\section{Associate Editors (Assignment Year)}

Jason Bond, Stoneville, MS (2010)

Kevin Bradley, Columbia, MO (2012)

Barry Brecke, Jay, FL (2013)

Ian Burke, Pullman, WA (2007)

Peter Dittmar, Gainesville, FL (2016)

Steve Fennimore, Salinas, CA (2004)

Aaron Hager, Urbana, IL (2012)
Brad Hanson, Davis, CA (2013)

Prashant Jha, Huntley, MT (2016)

Amit Jhala, Lincoln, NE (2018)

William Johnson, West Lafayette, IN (2007)

Andrew Kniss, Laramie, WY (2016)

Drew Lyon, Pullman, WA (2018)

Patrick McCullough, Griffin, GA (2016)

Scott McElroy, Auburn, AL (2012)
Robert Nurse, Guelph, ON (2016)

Darren Robinson, Ridgetown, ON (2008)

Larry Steckel, Jackson, TN (2007)

Daniel Stephenson, Alexandria, LA (2013)

Mark VanGessel, Georgetown, DE (2013)

Michael Walsh, Crawley, Australia (2016)

Eric Webster, Baton Rouge, LA (2018)

Cammy Willett, Fayetteville, AR (2017)

Tracy Candelaria, Managing Editor

\section{Officers of the Weed Science Society of America}

http://wssa.net/society/bod/

Weed Technology (ISSN 0890-037X) is published by the Weed Science Society of America, 12011 Tejon Street, Suite 700, Westminster, CO 80234. It is published bimonthly, one volume per year, six issues per year beginning in February.

Membership includes online access to Weed Technology, Weed Science, Invasive Plant Science and Management, and the online WSSA Newsletter. Dues should be sent to WSSA, 12011 Tejon Street, Suite 700, Westminster, CO 80234 no later than December 1 of each year. Membership in the society is on a calendar-year basis only.

New subscriptions and renewals begin with the first issue of the current volume. Please visit the Weed Technology subscription page at https://www.cambridge.org/core/journals/weed-technology/subscribe; Email: subscriptions_newyork@cambridge.org in USA, journals@cambridge.org outside USA.

Weed Technology publishes six times a year in February, April, June, August, October, and December. Annual institutional electronic subscription rates: US \$369.00; UK £257.00.

Please use Editorial Manager to access manuscript submissions (http://www.editorialmanager.com/wt). Authors are asked to pay $\$ 85$ for the first page and $\$ 65$ per page thereafter as a portion of the cost of publication, plus an additional processing charge of $\$ 55$ per manuscript if none of the authors are WSSA members. The Editor can make exceptions in advance when justified.

The Weed Science Society of America fully subscribes to the belief that progress in science depends upon the sharing of ideas, information, and materials among qualified investigators. Authors of papers published in Weed Technology are therefore encouraged, whenever practicable and when state and federal laws permit, to share genotypically unique propagative materials they might possess with other workers in that area who request such materials for the purpose of scientific research.

Weed Technology published by the Weed Science Society of America.

Copyright 2018 by the Weed Science Society of America.

All rights reserved. Reproduction in part or whole prohibited.

\section{Cover}

Preemergence and postemergence treatments with bicyclopyrone produced minor bleaching and stunting symptoms on watermelon early in the season, but symptoms were ephemeral and not detected late in the season. Watermelon yields and fruit number were consistent among all treatments, indicating that bicyclopyrone is safe for use in watermelon under the tested conditions. 


\section{WEED}

VOLUME 32

\section{TEC} ECHNO

\section{- WEED MANAGEMENT-MAJOR CROPS}

Physiological Basis for Tall Fescue (Festuca arundinacea) Tolerance to Florasulam. Jialin Yu, Patrick E. McCullough,

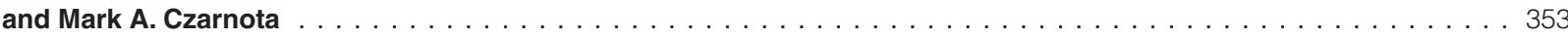

Rush Skeletonweed (Chondrilla juncea) Control in Pacific Northwest Winter Wheat. John F. Spring, Mark E. Thorne,

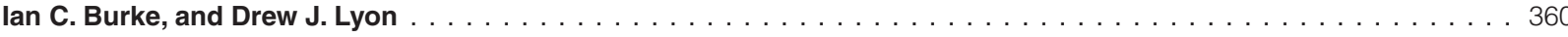
Residual Activity of ACCase-Inhibiting Herbicides on Monocot Crops and Weeds. Zachary D. Lancaster, Jason K. Norsworthy, and Robert C. Scott.

\section{- RESEARCH ARTICLE}

Benzobicyclon as a Post-Flood Option for Weedy Rice Control. Mason L. Young, Jason K. Norsworthy, Robert C. Scott, Jason A. Bond, and James Heiser.

\section{- WEED MANAGEMENT-MAJOR CROPS}

Effect of Formulations and Spray Nozzles on 2,4-D Spray Drift under Field Conditions. Augusto Kalsing, Caio V. S. Rossi, Felipe R. Lucio, Luiz H. S. Zobiole, Luis C. V. da Cunha, and Guilherme B. Minozzi

\section{- WEED MANAGEMENT-OTHER CROPS/AREAS}

Managing Cool-Season Weeds in Sugarbeet Grown for Biofuel in the Southeastern United States. W. Carroll Johnson, III,

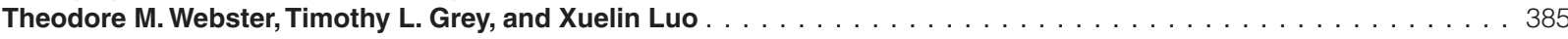
Evaluation of Verticutting and Herbicides for Tropical Signalgrass (Urochloa subquadripara) Control in Turf. David G. Pearsaul, Ramon G. Leon, Brent A. Sellers, Maria L. Silveira, and D. Calvin Odero

\section{- WEED MANAGEMENT-MAJOR CROPS}

Row Crop Sensitivity to Low Rates of Foliar-Applied Florpyrauxifen-benzyl. M. Ryan Miller and Jason K. Norsworthy . . . . 398

\section{- RESEARCH ARTICLES}

Assessment of Florpyrauxifen-benzyl Potential to Carryover to Subsequent Crops. M. Ryan Miller and

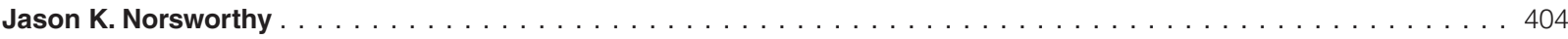
Response of Walnuts to Simulated Drift Rates of Bispyribac-Sodium, Bensulfuron-Methyl, and Propanil. Mariano F. Galla,

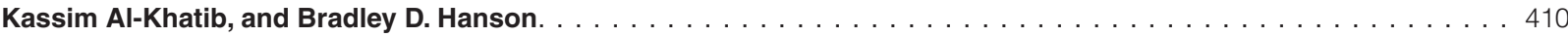
Enlist E3 ${ }^{\mathrm{TM}}$ Soybean Sensitivity and Enlist ${ }^{\mathrm{TM}}$ Herbicide-Based Program Control of Sumatran Fleabane (Conyza sumatrensis). Rafael L. Frene, David M. Simpson, Marcos Baez Buchanan, Ernesto Teran Vega,

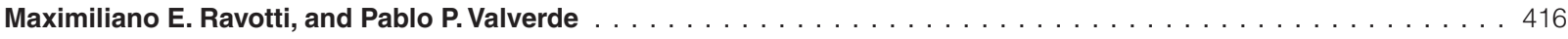
Weed Control and Tolerance of Sulfonylurea Herbicides in Caladium. Jialin Yu and Nathan S. Boyd . . . . . . . . . . 424 Evaluation of Cotton Responses to Fomesafen-Based Treatments Applied Preemergence. Xiao Li, Timothy Grey, William Vencill, James Freeman, Katilyn Price, George Cutts III, and Andrew Price . . . . . . . . . . . . . . 431 Effect of Bicyclopyrone on Triploid Watermelon in Plasticulture. Matthew B. Bertucci, Katherine M. Jennings, David W. Monks, David L. Jordan, Jonathan R. Schultheis, Frank J. Louws, and Matthew D. Waldschmidt.

Soybean Flower and Pod Response to Fomesafen, Acifluorfen, and Lactofen. Shawn C. Beam, Michael L. Flessner,

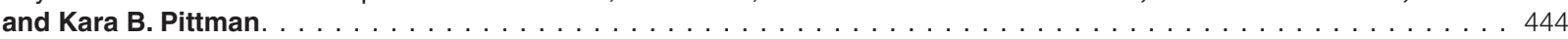
Influence of Plant Growth Stage and Temperature on Glyphosate Efficacy in Common Lambsquarters (Chenopodium album). Randy D. DeGreeff, Aruna V. Varanasi, J. Anita Dille, Dallas E. Peterson, and Mithila Jugulam.

\section{- WEED BIOLOGY AND COMPETITION}

Residual Herbicide Effect on Interseeded Annual Clover in Southern Forage Systems. Jennifer J. Tucker,

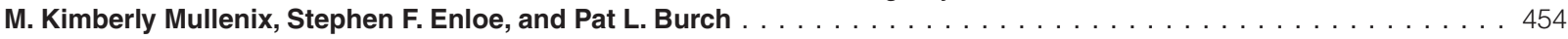
Vegetation Control and Soil Moisture Depletion Related to Herbicide Treatments on Forest Plantations in Northeastern Oregon. Elizabeth Cole, Amanda Lindsay, Michael Newton, and John D. Bailey . . . . . . . . . . . . . . . 46 


\section{- EDUCATION/EXTENSION}

Managing Wicked Herbicide-Resistance: Lessons from the Field. Jill Schroeder, Michael Barrett, David R. Shaw, Amy B. Asmus, Harold Coble, David Ervin, Raymond A. Jussaume Jr., Micheal D. K. Owen, lan Burke,

Cody F. Creech, A. Stanley Culpepper, William S. Curran, Darrin M. Dodds, Todd A. Gaines, Jeffrey L. Gunsolus, Bradley D. Hanson, Prashant Jha, Annie E. Klodd, Andrew R. Kniss, Ramon G. Leon, Sandra McDonald, Don W. Morishita, Brian J. Schutte, Christy L. Sprague, Phillip W. Stahlman, Larry E. Steckel, and Mark J. VanGessel .

Managing Herbicide Resistance: Listening to the Perspectives of Practitioners. Procedures for Conducting Listening Sessions and an Evaluation of the Process. Jill Schroeder, Michael Barrett, David R. Shaw, Amy B. Asmus, Harold Coble, David Ervin, Raymond A. Jussaume Jr., Micheal D. K. Owen, lan Burke, Cody F. Creech, A. Stanley Culpepper, William S. Curran, Darrin M. Dodds, Todd A. Gaines, Jeffrey L. Gunsolus, Bradley D. Hanson, Prashant Jha, Annie E. Klodd, Andrew R. Kniss, Ramon G. Leon, Sandra McDonald, Don W. Morishita,

Brian J. Schutte, Christy L. Sprague, Phillip W. Stahlman, Larry E. Steckel, and Mark J. VanGessel .

\section{- NOTE}

Safety of Bicyclopyrone on Several Vegetable Crops and Efficacy of Weed Control. Yin Chen, Chengsong Hu, and

Douglas Doohan. 